\title{
Compassion and mercy are not helpful in resolving intractable family-physician conflicts on end-of-life care
}

\author{
John J. Paris ${ }^{1}$ Brian M. Cummings ${ }^{2,3} \cdot$ M. Patrick Moore ${ }^{4}$
}

Received: 25 October 2018 / Accepted: 29 October 2018 / Published online: 23 November 2018

(c) Springer Nature America, Inc. 2018

\begin{abstract}
"Compassion and mercy" are important values for humanizing medicine. There are limits, however, in their ability to help resolve disputes between physicians and families regarding appropriate end-of-life care. The recent cases of Charlie Gard and Alfie Evans in England highlight the issue. The English courts resolve such conflicts by an independent assessment of a court. The American judicial system does not share the centralized system of the English courts. In the United States Federal structure some 50 state legislatures and 50 state court systems go their separate ways. The result is differing, frequently conflicting, standards. We explore possible ways to avoid court involvement in the American context for resolving such disputes within the patient-physician relationship.
\end{abstract}

\section{Introduction}

Such diverse sources as Prime Minister Mahathir Mohammed of Malaysia [1] and Pope Francis have issued public calls for compassion and mercy to be aspects of public policy [2]. In the case of Prime Minister Mohammed, the issue was about the caning of two lesbians. The Prime Minister labeled the caning, "contrary to the compassion of Islam.” For Pope Francis, who declared 2017 'A Holy Year of Mercy,' compassion and mercy rather than a concern for law and punishment ought to be the hallmark of the Church. He prefers describing the Church as a "field hospital" that cares for the afflicted and wounded rather than a gathering of the righteous. In his words, "I see the Church as a field hospital after battle." [3] Two highly publicized legal cases in Great Britain, Charlie Gard [4, 5] and Alfie Evans [6], highlight the issue of compassion and mercy in health care.

John J. Paris

john.paris@bc.edu

1 Boston College, 140 Commonwealth Ave, Chestnut Hill, MA 02467, USA

2 Department of Pediatrics, Massachusetts General Hospital, MGH Pediatrics Ethics Committee, 55 Fruit St, Boston, MA 02119, USA

3 Harvard Medical School, Boston, MA 02115, USA

4 Boston College Law School, 885 Centre St., Newton, MA 02459, USA

\section{The Charlie Gard case}

The Gard case involved a 9-month-old infant who had been in the intensive care unit (ICU) of London's Great Ormond Street Hospital (GOSH) for more than 6 months. He was hospitalized for treatment of a rare genetic disorder called encephalomyopathic mitochondrial DNA depletion syndrome (MDOS). His treating physicians and the experts consulted on his case were unanimous that there was no known treatment for Charlie's form (RRM2B) of the disorder. His physicians believed he could probably experience pain and agreed that there was nothing medicine could do to improve Charlie's medical condition. They proposed allowing the boy "to die with dignity."

Charlie's parents vehemently disagreed. They desperately wanted to try an experimental treatment (nucleoside therapy) proposed by a physician in the United States. The parents had raised $£ 1.3$ million by public subscription to cover the cost of the treatment. The American physician, initially noted in the court record as "Dr. I", was subsequently identified as Michio Hirano MD of New York's Columbia Medical Center.

Charlie's physician's at GOSH petitioned the British High Court to block the transfer on the grounds that nucleoside therapy had never been utilized on the form of disease afflicting Charlie, his potential for suffering from the unproven treatment, and the burden of additional months of ICU treatment that in their view offered no potential benefit to the patient. Justice Nichols Francis of 
the High Court, with what he commented was "The heaviest of hearts, but with complete conviction for Charlie's best interests" ruled in favor of the physicians' petition. That decision was subsequently upheld as a matter of British law by the Appeals Court, the UK Supreme Court and the European Court of Human Rights [7]. Every court that addressed the dispute noted its great empathy for the plight of the parents.

\section{Media reactions to Gard case}

The dispute was quickly sensationalized. One bioethicist wrote "Little Charlie Gard has been sentenced to die by those who hold power over him in the United Kingdom." [8] An even more forceful statement was published by Michael Brendan Dougherty in The National Review [9] who wrote that the state should "get out of the way" of the parents who were acting in the best interests of the child and allow the parents and other doctors "who reasonably believe [italics added] this other treatment could help."

A yet more inflammatory article was published in Breitbart News under the headline "Pope Francis Reverses Vatican Judgment on Charlie Gard, Siding with Parents." [10] The author noted, "Pope Francis expressed his support for the parents of Charlie Gard, suggesting they be allowed to do everything possible to treat their son." That reading of the pope's comments was the writer's interpretation of an official Vatican statement that the pope had been following the parents" case "with affection and sadness," praying "that their desire to accompany and care for their own child to the end is not ignored." The pope's statement was one of pastoral concern, not an analysis of the appropriate use of medical treatments in this case.

The story took on a broader context when the New York Times published comments of the pope under the headline "Dispute Over British Baby's Fate Draws in Pope and U.S. President." [11] Neither the Breitbart account nor the New York Times article provided a detailed analysis of the Gard case, let alone an explanation of any purported change in Catholic teaching on the care of profoundly ill patients.

\section{The Alfie Evans case}

Similar headlines accompanied the case of Alfie Evans, a four-month old British infant who was hospitalized at Liverpool's Alder Hey Hospital [12]. Alfie was afflicted by an unidentified neurodegenerative disorder that reduced much of his brain to cerebral fluid. Alfie's parents wanted to transfer him to Bambino Gesù Hospital, a Vatican pediatric facility in Rome. All the doctors in the Evans case, including those brought in by his parents, agreed that a therapeutic intervention for the infant's medical condition was impossible. "Comfort care" was the only known response for Alfie's condition. The physicians at Alder Hey Hospital wanted to remove the medical interventions that they believed were delaying the infant's death. His parents wanted the opportunity to transfer him to Rome's Bambino Gesù Hospital.

\section{Intervention of Pope Francis}

After Pope Francis had a private meeting at the Vatican with Alfie's father and had expressed his interest in the plight of little Alfie, a public clamor arose to transfer Alfie to Rome's Bambino Gesù. "Alfie's Army," a group who supported the parents' plans for the transfer, threatened to remove the infant from the Alder Hey Hospital and take him to Bambino Gesù for "treatment."

Cardinal Vincent Nichols, the archbishop of Westminster and leader of the Catholic Church in England Wales, issued a press release that he believed everything possible had been done to help Alfie. He was also critical of those who "sought political capital" from the tragedy "without knowing the facts." In his words, "that is why a court must decide what's best — not for the parents but for the child." The members of Alfie's Army were not deterred by the Cardinal's statement. They continued to express support for the parents' decision to transfer the infant to Bambino Gesù.

\section{Role of parents in medical decision making for their children}

While parents generally bear the responsibility for medical decisions for their children, the British parliamentary Children's Act of 1989 makes clear that the idea that parental rights regard children as possessions is an outdated notion [13]. The creation of child protective agencies is evidence that parents can, and sometimes do, make decisions antithetical to the interests of their children. Even good, caring, loving parents can make choices contrary to the child's interest—not necessarily out of malice-but from a lack of understanding of their child's medical condition, anxiety, fear or unrealistic hopes and expectations. Desperate parents of profoundly compromised children are desperate. Some cannot psychologically make a decision that will end their child's life [14]. Some will grasp at any hope, no matter how improbable or remote. It is in such situations that the physician's fiduciary responsibility to act as an advocate for the child's welfare [15] as well as the state's parens patriae responsibility to protect the vulnerable patient become operative [16].

There is little ambiguity on the social networks, in the media and among the public for the parents' decisions in the Gard and Evans cases. Michael Dougherty's comments in The National Review aptly sum up the public's sentiment: The state should "get out of the way of the parents trying to 
act in the best interests of the child." Even Dougherty though, conceded that the parents' choice "may be the wrong decision." Nonetheless, he insisted that "it should still be their decision." Then without any documentation or supporting evidence he observed, "Other parents whose children suffered from a similar condition and were deemed to have no hope have seen recovery through this therapy." Even the New York doctor who proposed trying nucleoside therapy for Charlie acknowledged in telephone testimony to the High Court that the therapy had never been tested, even in animal studies, for the mutation afflicting Charlie. He also agreed the damage to Charlie's brain was largely "irreversible."

Mr. Justice Nicholas Francis in his finding of facts in the Gard case noted, "No one in the world has ever treated this form of MDDS (RRM2B) with nucleoside therapy." That therapy had been used with a different mutation (TK2) with some limited success (a $4 \%$ increase in life expectancy in a study of mice). He continued, "There is no evidence that nucleoside therapy can cross the blood/brain barrier which it must do to treat the form of mutation Charlie Gard had."

\section{Limitations on requests for medical interventions}

The question arises as to what if any limits there are to a patient, or in the case of a minor, of parents' claims for a desired medical treatment. While in the United States there is a long line of cases starting in 1914 with Schloendorff $v$. Society of New York Hospital [17] and culminating in the U. S. Supreme Court's 1990 opinion in Cruzan v. Director, Missouri Department of Health on the right of a patient or proxy to decline an unwanted medical treatment [18], there is no such tradition upholding a patient's claim to whatever medical treatment the patient or proxy may desire.

From reflections as early as the Hippocratic Corpus, we read of three roles for medicine: "doing away with the suffering of the sick, lessening the violence of their diseases, and refusing to treat those who are overmastered by their disease, realizing that in such cases medicine is powerless." [19] In a commentary in Book III of The Republic Plato admonishes, "Medicine isn't intended to such people... even if they are richer than Midas." [20] Doing so, he observed, would make their life a "prolonged misery."

\section{British legal tradition}

Mr. Justice Francis noted in his opinion in the Gard case the issue was not about money. In his words, "If anyone were to support that Charlie would have nucleoside treatment but for the cost [to the NHS], they would be completely wrong." Cost, Justice Francis acknowledged, is a factor in the provision of medical treatment in the United States. As he wrote in his opinion, "The US doctor made it clear that were Charlie in the United States," he would treat him if the parents so desired and could pay for it. "[italics added]" [21].

In Justice Francis' view the dispute between the parents and physician in the Gard case was whether or not the experimental therapy ought to be tried on Charlie. In the Evans case, the issue was should the infant who had incurred irreversible neurological devastation be subjected to continued ICU interventions.

As both Justice Francis and Justice Hayden noted in their respective opinions, the cases were resolved on the long standing British tradition that once any party in a dispute has recourse to the court, a court's independent assessment of the patient's best interests is the only factor to be considered. In his opinion Mr. Justice Francis raised the question of "why should the parents not be the ones to decide." As he explained, "in the United Kingdom overriding control is vested in the court, exercising its independent and objective judgement in the child's best interest."

In an earlier High Court case, An NHS Trust v. MB [22] Mr. Justice James Holman laid out the standards which judges are to follow. He insisted the judge is not to decide what he himself would do in such a situation, nor whether the respective decisions of the parents or those of the physician were "reasonable." Holman also stressed that the views of the parents are not dispositive. In his forceful phrasing, "Their own wishes, however understandable in human terms, are wholly irrelevant to consideration of the objective best interests of the child."

Mr. Justice Francis concluded his reflections on the British approach with a citation from Lord Donaldson, the Master of the Roll, in the 1991 case of Re J. Lord Donaldson, the second highest ranking jurist in England and Wales, noted that while there is a strong presumption in favor of prolonging life "in the end there will be cases in which the answer must be that it is not in the interest of the child to subject it to treatment which will cause it increased suffering and produce no commensurate benefit." [23]

A similar assessment was made by Mr. Justice Hayden in the Alfie Evans case when he ruled that the parents "would achieve nothing" through their plan to move Alfie to Rome. In reaching that conclusion Justice Hayden noted that Pope Francis and the Catechism of the Catholic Church approved the refusal of 'over-zealous treatment' which the Catechism defined as "Discontinuing medical procedures that are burdensome, dangerous, extraordinary, or disproportionate to the expected outcome." Justice Hayden quoted from No. 2278 of the Catechism: "Here one does not will to cause death; one's inability to impede it is merely accepted." [24] 


\section{Best interest standard}

After years of shifting standards on medical treatments, there is now a strong consensus in the medical and ethical literature that it is the best interests of the patient, not the desires of the family or the personal predilections of the physician, that ought to prevail [25]. That standard does not rest on autonomy or an attempt to determine what the patient would have wanted, but solely on a concern for the patient's welfare. Such protection is particularly important with regard to infants and children because with it they are now seen not merely as the pawns of parents, but as patients in their own right [26]. The implication is that although parents may continue to be involved in decision making for their children, they do not have an absolute right to refuseor to require-medical treatment for their child. Translated into practice as was done in guidelines on the care of highrisk newborns promulgated in 2007 by the American Academy of Pediatrics that standard means if the burden on the infant is overwhelming or the prospects are extremely bleak, as was true in the cases presented in this paper, there is no obligation to use intensive care [27].

\section{Do "Compassion and Mercy" factor into the resolution of family-physician disputes on end-of- life care}

How does this consensus on "best interests standard" impact the call for "compassion and mercy" in the formation of public policy on medical decision making? The Gard and Evans cases show the dangers of focusing other than on such interests: the fickleness of public sentiments, the degrading of scientific evidence and the potential for endless demands for untested and unproven treatments. Such demands, Lester Thurow noted in a now classic essay entitled "Learning to say 'No," [28] presage fiscal insolvency. To avoid the inevitable financial bankruptcy that follows from such a course, Thurow proposed that we are going to have to learn to say 'No' to requested medical treatment, not because there is no value in the treatmentsuch as mercy for the patient or compassion for the parents -but because in economic terms "the marginal costs exceed the marginal benefit," or in the language of sciencebased medicine, "There is no evidence that the requested intervention works."

\section{The American experience}

The saga of the Terri Schiavo case-which continued from 1990 to 2005 and involved multiple state and federal courts, the Florida legislature, Florida's Governor Jeb Bush, the US Congress, President George W. Bush, some 14 appellate hearings, and 4 denials of certiorari by the US Supreme
Court--serves as a warning to those who postulate compassion as a way to resolve physician-family conflicts in end-of-life care. That challenge is even greater when we consider the physician-family dispute in the case of Baby $\mathrm{K}$ [29], a child whose mother insisted on continued ventilator support and ICU care for her infant daughter who was born with anencephaly, i.e., no brain. That case ended only after a 45 minute failed attempt at cardiopulmonary resuscitation when the 21/2-year-old infant suffered a cardiac arrest.

Even more challenging is the case of Jahi McMath, a 13year-old girl who following complex surgery was diagnosed by her treating physicians at Oakland Children's Hospital as 'brain-dead.' [30] Jahi's mother protested that her daughter, who was in the ICU on a ventilator, was breathing, her heart was beating and her body was warm and moist, could not be dead. The mother brought a law suit in the Alameda, California Superior Court. There the presiding judge appointed the chief of pediatric neurology at Stanford Medical Center to assess the patient's medical status. After a comprehensive physical examination, the court appointed physician informed the judge that Jahi McMath met the statutory criteria for brain-death. The judge ruled Jahi McMath was "legally dead." The coroner issued a death certificate.

Despite those medical and legal findings, Jahi's mother insisted her daughter was alive. In her words "She is not dead. She [just] needs time to get better." [31] The mother went even further when she declared, "In this country, a parent has the right to make decisions concerning the existence of their child." [32] The economic and public health implication of millions of individuals determining who is, and who is not, dead are staggering.

Jahi McMath, while the best-known case of parental denial of a child's death, is not unique. Similar cases occurred in 1994 at Florida's Sarasota Memorial Hospital [33], New York's St. Vincent Hospital in 1995 [34], Utah [35] and Washington, DC in 2008 [36]. On June 22, 2018, in a New Jersey hospital some five years after she was pronounced "legally dead" by a California judge, Jahi McMath succumbed to liver failure. Her family accepted the fact of her demise. She was buried in California [37].

\section{Discussion}

In a moving challenge to Shylock's demand for "justice" in Shakespeare's The Merchant of Venice [38] Portia reminds us, as does the Prime Minister of Malaysia and Pope Francis, that "mercy" not "justice" is the virtue rulers ought to utilize in their governance. In health care compassion and mercy are cherished values. They humanize medicine. Great though they be for emphasizing the role of dignity and human values in medicine, 'compassion and mercy' are not 
necessarily helpful in resolving intractable standoffs between families and physicians on the appropriate approach to care for the patient "overmastered by disease." Such situations, as Hippocrates and Plato observed, are beyond the scope of medicine.

As we have noted, the carefully crafted opinion of Justice Francis in the Gard case resolved the dispute within the British legal tradition. Nonetheless, the Gard opinion, as did that of Justice Hayden in the Evans case, left the public dissatisfied. The conflict involving Charlie Gard went unresolved for nearly a year. Charlie endured months of aggressive ICU care his physicians at Great Ormond Street Hospital had sought to avoid. His parents, as well as those of Alife Evans, had to endure their child's prolonged and controversial dying process. In the end neither patient or family, nor the medical community or society were well served by the process.

Does the application of 'compassion and mercy' within the medical community provide a better resolution? The examples of family-physician disputes examined in this essay give no evidence of such an outcome.

The British, with a more unified judicial system than that of the United States, have settled on the independent assessment of a court to resolve these issues. As we learn in Alexis de Tocqueville's Democracy in America [39], midnineteenth century Americans were smitten by the idea that courts could transform life's moral dilemmas into readily soluble legal problems. It was as if judges, unlike mere mortals, somehow transcend the limitations of human nature. On donning their judicial robes judges become, as it were, Platonic gods. Experience establishes no such transformation occurs on assuming the judicial role [40].

\section{A proposed resolution}

The disagreements on how best to resolve family-physician conflict occasioned an intense debate in the literature [41]. The so called "futility" debate began with the report in 1990 on the case of Baby L, in which physicians at Boston Children's Hospital refused as "futile" a parental request for ventilator support for a neurologically devastated 23-monthold infant [42]. The term "futility" proved impossible to define with any precision or agreed upon meaning. The "futility" argument soon met its demise as a short hand way to resolve family-physician conflicts with the publication in 2000 of an article by Helft and colleagues on the rise and fall of the futility movement [43].

The failed attempt to utilize 'futility' language to resolve family-physician disputes was soon replaced in American bioethics with a process-based approach first seen in a Texas case, Hudson v. Texas Children's Hospital [44]. That approach demonstrated that there was a way out of the conundrum American medicine seemingly faced of being forced to accede to family demands or engage in an adversarial process by challenging family's demands in court. The case involved a full-term infant named Sun Hudson, who was born with thanatropic dysplasia, a severe genetic form of dwarfism that frequently results in early death from respiratory failure [45]. At delivery the physicians, unaware of the fetus's medical status, resuscitated the infant and placed him on a ventilator. A subsequent evaluation revealed the baby had "a lethal and incurable genetic deformity." The team of neonatologists and bioethicists at Texas Children's determined it would be unethical to continue ventilator support on an infant they believed was "slowly suffocating." Sun's mother did not accept that assessment. As she puts it, "He just needs to finish growing." Further, she informed the doctors, "The sun that shines in the sky, not a man, fathered her child and would decide its fate." [46]

Unlike most states where the only alternative to following a family's care plan was to challenge it in court, a 1999 Texas statute [47] authorizes a "processed-based approach" whereby physicians and hospitals may withdraw lifeprolonging interventions even over family objections if the actions were approved by an ethics committee and no other facility could be found within 10 days willing to treat the patient as the family wished [48]. Some 40 hospitals declined to accept Sun Hudson on transfer. Ultimately, a probate court ruled that under the statute the hospital was authorized to withdraw treatment. Once provided with judicial approval, the treating physicians withdrew the respirator. The patient died almost immediately.

While there is still no agreement on a definition of medical futility, the Texas statute reserves that determination for an ethics committee judgment. The committee's judgment is constrained by communal standards because a healthcare institution may not withdraw treatment if another facility is willing to provide it. It is only when no qualified physician has been identified who is willing to accede to the requested life-sustaining treatment that it may be withdrawn. In light of the general success of that approach in keeping disputes about medical treatment in the U.S. out of court, policy statement from multiple professional societies now recommend a process-based approach [49].

In the Gard and Evans cases, unlike that of Sun Hudson, there were physicians and institutions willing to accept care of the child. Had the transfer occurred the treating physicians, as frequently happens in cases where a second opinion is sought, would given over care of the patient to another physician. Although the outcome might well have been unchanged, the parents request would have been honored and public outcry avoided. 


\section{Weaknesses and strengths of process-based approach}

There is no question profit-oriented physicians might game such a system for personal gain, or doctors might revert to the practices found in the early heart-transplant literature of experimenting on poorly qualified candidates [50-52]. Purveyors of snake oil might once again exploit vulnerable patients. Alternatively, courts would not be burdened with endless disputes between families and physicians, conflicts better resolved other than in the judicial process. End-of-life decision making would revert to the patient-physician relationship.

\section{Experience of a physician confronting family- physician conflicts}

In a recent essay in The New England Journal of Medicine a medical resident in England recounts her encounters with such conflicts. In her hospital practice she experienced, as Dostoyevsky tells us is common in his poem on "The Grand Inquisitor" in The Brothers Karamazov, people do not want to accept responsibility for difficult decisions. They might desire the outcome, but do not want the anxiety, burden or guilt associated with a decision that ends the life of anther, particularly when the other is a family member. As the author observed in her essay, medicine is not just about treating illness. It can often involve appreciating the necessity to say 'no' while allowing the patient (or family) to say 'yes.' [53]

\section{Conclusion}

Compassion and mercy are virtues lauded in multiple religious traditions. They might better remain in that realm. Not co-opted by the medical community to resolve issues better handled within the patient-physician relationship. Compassion for the family and mercy for the patient can be achieved by acknowledging and accepting a family's reluctance to be the ones articulating a decision no family member wants to make, one to end the life of another. Doing so also enhances the dignity of the dying patient. The patient does not want to be pushed over the cliff, nor do family members want to be perceived as having done so. Here one is reminded of Franz Inglefinger's final address at Harvard Medical School where he told the students that it was their responsibility as physicians to lift the burden of difficult decisions from the patient's shoulders and bear the responsibility of making a recommendation. Anything less, he admonished, "Would not warrant the somewhat tarnished but still distinguished title of doctor." [54]

\section{Compliance with ethical standards}

Conflict of interest The authors declare that they have no conflict of interest.

\section{References}

1. Young, HH. Malaysia PM says caning of lesbians counter to 'Compassion of Islam https://www.usnews.com/news/world/a rticles/2018-09-06/malaysian-pm-says-caning-of-lesbianscounter-to-compassion-of-islam. Accessed 11 Sept 2018.

2. Francis P. A big heart open to god. America Mag. 2013, p. 2.

3. Coday, D. The field hospital church. National Catholic Reporter 2013, p. 1.

4. Great Ormond Street Hospital v. Yates and Gard [2017] EWHC 972 (Fam) (England and Wales High Court Family Decision), April 11, 2017, http://www.bailii.org/ew/cases/EWHC/Fam/2017/ 972.h5ml. Accessed 4 Sept 2017.

5. Paris JJ, Ahluwalia J, Cummings BM, Moreland MP, Wilkinson DJ. The Charlie Gard case: British and American approaches to court resolution of disputes over medical decisions. J Perinatol. 2017;37:1268-71.

6. Clark K. Alfie's last days: a little boy's life and death stoked a furious debate that will not soon end. America Mag. 26 April 2018. https://www.americamagazine.org/politics-society/2018/08/ 04/26/alfies-last-days-little-boys-life-and-death-stoked-furiousdebate-will-not-soon-end. Accessed 4 July 2018.

7. Gard and Others v. The United Kingdom, European Court of Human Rights. 3 July 2017, https://hudoc.echr.int/eng\# \{ "itemid": [“001-175359"]\}. Accessed 4 Sept 2017.

8. Camosy C. On the Charlie Gard case, the church needs to be clear. CRUX, 3 July 2017. https://cruxnow.com/commentary/2017/07/ 03/charlie-gard-case-church-needs-clear-prophetic/html. Accessed 12 Aug 2017.

9. Dougherty MB. The Vatican's statement on the Charlie Gard case is a disgrace. The National Review. 30 June 2017. http://www.na tionalreview.com/article/449159/vatican-charlie-gard-statementsides-state-over-family. Accessed 13 Aug 2017.

10. Williams TD. Pope Francis Reverses Vatican Judgment on Charlie Gard Case, siding with parents. Breitbart News, 3 July 2017 at 1. http://www.breitbart.com/london/2017/07/03/pope-fra ncis-reverses-vatican-judgment-charlie-gard-siding-parents. Accessed 12 Sept 2017.

11. Bilefsky D, Chan S. Dispute oer British Baby's fate draws in Pope and U.S. President. NY Times, 3 July 2017. https://www.nytimes. com/2017/07/03/world/europe/uk-trump-pope-francis-charlie-ga rd.html?_r=o. Accessed 12 Sept 2017.

12. Clark K. The life and death of Alfie Evans. Am Mag. 2018;26:2833.

13. UK Parliament, The Children's Act 1989. Granted Royal Assent on 16 November 1989 and became an Act House of Commons, Tuesday 16 November 1989. Parliamentary Debates (Hansard). House of Commons. 16 November 1989. col 457. https://publications.parlia ment.uk/pa/cm198889/cmhansrd/1989-11-16/Debate-1.html.

14. Paris JJ, Graham N, Schreiber MD, Goodwin M. Has the emphasis on autonomy gone too far? Insights from dostoevsky on parental decisionmaking in the NICU. Camb Q Healthc Ethics. 2006;15:147-51.

15. Paris J, Bell A. Guarantee my child will be "normal" or stop all treatment. J Perinatol. 1993;13:469-72.

16. People V. Bennett: analytic approaches to recognizing a fundamental parental right under the ninth amendment. BYU Law Rev. 1996;186:227-34. 
17. Schloendorff v. Society of New York Hospital, 105 N. E. 92 (1914).

18. Cruzan v. Director, Missouri Department of Health 476 U.S. 261.

19. Amundsen DW. The physician's obligation to prolong life: a medical duty without classical roots. Hastings Cent Rep. 1978;8:23-30.

20. Plato. The Republic, Book III (trans. Allan Bloom) 3rd ed. New York: Basic Books;1992. p. 408-26.

21. Great Ormond Street Hospital v. Yates and Gard [2017] EWHC 1909 (Fam) 24 July 2017. Case No. FD17P00103. https://www. judiciary.gov.uk/judgments/great-ormond-street-hospital-v-ya tes-and-gard-24-july-2017. Accessed 5 Sept 2017.

22. An NHS Trust v. MB [2006] 2 FLR 319.

23. Re J (A minor) (Wardship treatment) [1991] Fam 33 at p. 46.

24. Catechism of the Catholic Church. 2nd ed. Vatican Libreria Editrice 1992, No. 2278.

25. Caplan A, Cohen CB, editors. Imperiled Newborns. Hastings Cent Rep. 1987;17:5-32.

26. Bartholomew WG. The child-patient: do parents have the right to decide? In Spicker S, Englehardt T, Healey J, et al., editors. The law-medicine relation: a philosophical explanation. Dordrecht, Netherlands: Reidel;1981, p. 126-32.

27. Committee on Fetus and Newborn, American Academy of Pediatrics. Nonintervention or withdrawal of intensive care for high-risk newborns. Pediatrics 2007;119:401-3.

28. Thurow LC. Learning to say 'no'. N Engl J M. 1984;311:156972.

29. Annas GH. Asking the courts to set the standard of emergency care-the case of Baby K. N Engl J Med. 1994; 350:1542-4.

30. Paris JJ, Cummings BM, Moore MP. Brain-death,' 'death' and parental refusal: the case of Jahi McMath. Camb Q Healthc Ethics. 2014;23:371-82.

31. Dolan CB. A personal story of representing Jahi McMath. San Francisco Examiner 2013:1.

32. Brain-dead: Jahi McMath's family searches for options as lifesupport cut off looms. GlobalVille News at http://globalvillenews. com/tag/arthur-caplan. Accessed 17 Jan 2014.

33. Brain-dead florida girl will be sent home on life support. NY Times, 19 Feb 1994. http://www.nytimes.com/1994/02/19/vs/bra in-dead-floridagirl. Accessed 21 Jan 2014.

34. Paris JJ, Bell AJ, Murphy JJ. Pediatric brain-death: dead is dead. J Perinatol. 1995;15:67-70.

35. Collins LM, Thomas L. Jesse loses his battle with brain tumor. Desert News http://wwwdeseretnews.com/article/595106792/ Jesse-loses-his-battle-with-brain-tumor . Accessed 20 Jan 2014.

36. Alexander KL. Judge delays decision on removing life support. Wash Post 2008 Nov 11:B5. http://www.washingtonpost.com/wp-
days/content/article/2008/11/18/AR2008111001408.html Accessed 20 Jan 2014.

37. McMath J. The California girls in life-support controversy, is now dead. Wash Post, 29 June 2018 p. 1. https://www.washingtonpost. com/news/morning-mix/wp/2018/06/29/jahi-mcmath-the-califgirl-declared-brain-dead-4-years-ago-is-taken-off-life-support/? noredirect $=$ on\&utm_term $=.0 \mathrm{c} 88 \mathrm{c} 33 \mathrm{e} 2962$. Accessed 8 Oct 2018.

38. Shakespeare W. The Merchant of Venice Act IV, Scene 1. New York: Modern Library. p. 150-1. ISBN 978-1-58836-874-4.

39. Tocqueville de A. Democracy in America. New York: Bantam Classics; 2000.

40. Powell v. Columbia Presbyterian Medical Center, 49 Misc 2nd 215, 267 N.Y.S. 2nd 450 (1965).

41. Schneiderman LJ, Faber-Langendon K, Jecker NS. Beyond futility to an ethics of care. Am J Med. 1994;96:110-4.

42. Paris JJ, Crone R, Reardon F. Physicians' refusal of requested treatment: the case of Baby L. N Engl J Med. 1990;322:1012-5.

43. Helft P, Siegler M, Lantos J. The rise and fall of the futility movement. N Engl J M. 2000;343:293-6.

44. Hudson v. Texas Children's Hospital 2005 WL497818 (Tex. App -Hous. (1 Dist).

45. Paris JJ, Billings JA, Cummings BM, Moreland MP. Howe v. MGH and Hudson v. Texas children's hospital: two approaches to resolving family-physician disputes in end-of-life care. J Perinatol. 2006;26:726-9.

46. Nichols B. Hospital ends life support of baby: 1st case of its kind is against mom's wish, in accordance with law. Morning News, 15,2005 at A1.

47. Texas Health and Safety Code $§ 166.046(a)$ (Vernon Supp 2002).

48. Paris JJ, Cummings BM, Moreland MP, Batten JN. Approaches to parental femand for non-established medical treatment: reflection on the Charlie Gard care. J Med Ethics. 2018;1-4. 10.1136/ medethics-2018-104902.

49. Bosslet G. An official ATS/AACN/ACCP/ESICM/SCCM policy statement: responding to requests for potentially inappropriate treatments in intensive care units. Am J Respir Crit Care Med. 2015;191:1318-30.

50. Hunt SA. Taking heart-cardiac transplantation past, present and future. N Engl J Med. 2006;355:231-5. https://doi.org/10.1056/ NEJMp068048.

51. Bailey L, Nehisen-Connarella SL, Conception W, Jolley WB. Baboon-to-human cardiac transplantation in a neonate. JAMA. 1985;254:3321-9.

52. Blakeslee S. Baboon-heart implant in baby Fae in 1984 assailed as 'wishful thinking. NY Times. 1985;12-20 ISSN 0362-4331. Accessed 10 Oct 2018.

53. Caulley L. A seat at the table. N Engl J Med. 2018;3179:1400-1. 54. Ingelfinger F. Arrogance. N Engl J Med. 1980;303:1507-1511. 